\title{
Cluj, Romania 2003
}

\author{
By Ron Holloway
}

Fall 2003 Issue of KINEMA

\section{TRANSYLVANIA INTERNATIONAL FILM FESTIVAL CLUJ, ROMANIA 2003}

Last year, the $1^{\text {st }}$ Transylvania International Film Festival (TIFF) in Cluj (aka Cluj Napoca, to cite its Roman origin), situated in the northwestern corner of Romania near the Hungarian border, was greeted with enthusiasm by both public and visitors. The large home crowd, composed mostly of students from several universities and cultural institutions, had only one complaint: the festival, scheduled during the first week of June, happened to take place smack in the middle of school exams. Couldn't a better date on the calendar be found? As for the run of guests and tourists, they bothered Tudor Giurgiu, festival founder and director, almost daily with the same nagging question: "Where's Dracula's Castle, and how do I get there?" There were no complaints, however, in regard to the entries booked by critic Mihai Cherilov. Altogether, 45 films were programmed in two venues, with a competition open to first and second features.

Come the $2^{\text {nd }}$ TIFF (23-31 May 2003), and it was a giant step forward! More sponsors knocked on the door, and more financial input came from the government and local officials. Also, among the 90 films screened in three venues was a panorama of new features programmed under "Romanian Days". Two entries in this section were immediately picked to compete at major international festivals: Calin Netzer's Maria, awarded the Special Jury Prize at the recent Locarno International Film Festival, and Nicolae Margineanu's Bless You, Prison, to be seen at the upcoming Montreal World Film Festival. As for cineastes nurtured on Dracula and Nosferatu, a day trip to Sighisoara, a picturesque $13^{\text {th }}$-century museum town, was arranged to visit the birthplace of Vlad the Impaler. Along the way, the bus passed by another Romanian tourist attraction that was well worth a visit: a "gypsy mansion" recently erected and decorated like a sultan's palace.

The only festival snag, according to Rik Vermeulen, a program coordinator on loan from the Rotterdam Film Festival, was the price of the theatre tickets. Although ranging around a couple of Euros for an EC visitor, it was considered a bit too much for the pockets of some students. The situation was resolved by issuing "visitor passes" for screenings that hadn't proven a draw in advance at the box office. Next year, it was rumoured, the $3^{\text {rd }}$ TIFF will move back into early summer dates to permit the young crowd from cities across Romania to pilgrimage to Cluj for "a festival of films and fun" - along the lines of pack-backing crowds at Karlovy Vary.

Every festival has its faux pas. At Cluj 2003, it was the conspicuous absence of veteran Romanian director Lucien Pintilie for his own retrospective tribute. Some say it was because of the dispute that had arisen between himself and the young screenwriters on his latest film, Niki and Flo, programmed last May at Cannes in the Directors Fortnight and generally regarded by the critics as a flop. As for the winner of the Transylvanian Trophy, it went deservedly to an Icelandic entry: Dagur Kari's Noi Albanoi (Noi the Albino), the fetching tale of a young misfit in pursuit of a girl at the gas station who comes out in the end a winner he survives a catastrophe that suddenly hits the town.

\section{Author Information}

Ron HOLLOWAY (1933-2009) was an American critic, film historian, filmmaker and correspondent who adopted Europe as his home in the early fifties and spent much of his life in Berlin. He was an expert on the study of German cinema and against all odds produced, with his wife Dorothea, the journal German Film, keeping us up-to-date with the work of directors, producers and writers and the showing of German films around the world.

In 2007, Ron Holloway and his wife were awarded the Berlinale Camera Award. Ron also received the Bundesverdienstkreuz (German Cross of Merit), Polish Rings, Cannes Gold Medaille, the American Cinema Foundation Award, the Diploma for Support of Russian Cinema and an honorary award from the German Film Critics' Association. 
Ron was also a valued contributor to Kinema for the past fifteen years. 